\title{
PEMBUATAN KAPASITOR DENGAN BAHAN TIMAH SELENIDA (SnSe) TEKNIK FILM TIPIS
}

\section{MAKING CAPACITORS WITH SELENIDA TIN (SnSe) TIP FILM TECHNIQUES}

\author{
Yusnidah* \\ Politeknik Adiguna Maritim Indonesia Medan, Indonesia \\ Diterima: 04-07-2020; Disetujui: 20-07-2020; Dipublish: 30-07-2020 \\ *Corresponding Email: asdayusnidah@gmail.com
}

\begin{abstract}
Abstrak
Film tipis timah selendia ( $\mathrm{SnSe}$ ) dibuat dengan metoda selenisasi tertutup. Pengukuran arus bolak-balik untuk sampel berbentuk struktur terapit dengan elektroda aluminium (Al / SnSe / Al) dilakukan dalam ruang kriostat pada suhu di antara dalam ruangan kriostat pada suhu di antara (228-373)K. Parameter yang diukur adalah kapasitansi untuk frekuensi kurang dari $50 \mathrm{kHz}$, kapasitansi berkurang, terhadap frekuensi dan bertambah mengikuti suhu, sedangkan pada frekuensi lebih besar dari $50 \mathrm{kHz}$ kapasitas menjadi tetap. Konstanta dielektrik film adalah $\mathrm{e}_{\mathrm{r}}=12,13$, diperhitungkan dari grafik kapasitansi terhadap seper ketebalan sampel (1/d).
\end{abstract}

Kata Kunci: Film tipis, timah selenida (SnSe), elektroda aluminium

\begin{abstract}
Thin film of selendia tin ( $\mathrm{SnSe}$ ) is made by the method of closed selenisation. Measurement of alternating current for samples in the form of enclosed structures with aluminum electrodes (Al/SnSe/Al) is carried out in the cryostat chamber at an intermediate temperature in the cryostat chamber at a temperature between (228-373) K. The parameters measured are capacitance for frequencies less than 50kHz, capacitance decreases, with respect to frequency and increases with temperature, whereas at frequencies greater than $50 \mathrm{kHz}$ the capacity is fixed. The dielectric constant of the film is er =12.13, calculated from the graph of capacitance with respect to the thickness of the sample $(1 / d)$.
\end{abstract}

Keywords: Thin film, tin selenide (SnSe), aluminum electrodes

How to Cite: Yusnidah. (2020). Pembuatan Kapasitor Dengan Bahan Timah Selenida (Snse) Teknik Film Tipis, Journal of Natural Sciences. Vol 1 (2): 99-104

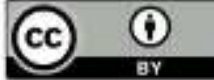

This work is licensed under a Creative Commons Attribution 4.0 


\section{PENDAHULUAN}

Timah selenida ( $\mathrm{SnSe}$ ) adalah sejenis bahan semikonduktor golongan IV-VI pada unsure berkala. Semikonduktor SnSe mempunyai konduktivitas jenis-p dapat berubah menjadi konduktivitas jenis-n jika didoping dengan atom antimoni (Sb). Sifat-sifat lain, energy terlarang yang senpit $\sim 1,0 \mathrm{eV}$, kerapatan pembawa muatan $\sim 10^{18} \mathrm{~cm}^{13}$ dan resistivitas, rendah $\sim 1 Q, \mathrm{~cm}$ sangat mendukung sebagai bahan yang berpotensi digunakan piranti elektronik, sel surya dan sensor hablur ortorambik SnSe mempunyai delapan atom per unit sel dengan parameter kekisi a =4,46 A, 4,19 A dan 11,59 A dan jarak atom Sn dan Se dalam hablur SnSe adalah 2,77 A, 2,82 A 3,35 A dan 3,47 A dan SnSe melebur pada suhu $880^{\circ} \mathrm{C}$.

Penyedia film tipis SnSe telah dilakukan barbagai metode diantaranya evaporasi, kimia, ipiteksi dan reaksi bahan padat. Dalam kajian ini, film tipis SnSe disediakan secara penselenidan, suatu metode yang meliputi proses evaporasi dan menyepuh dalam tabung tertutup, menganalisis sifat dielektrik film tipis SnSe dengan cara pengukuran arus bolak-balik belum banyak dilakukan kecuali perhitungan konstanta dielektrik untuk bahan bulk material SnSe (Logothetidis dan Palatoglour 1987). Tulisan ini melakukan penelitian analisis sifat dielektrik melalui pengukuran arus bolak-balik terhadap sturktur terapit film tipis $\mathrm{Al} / \mathrm{SnSe} / \mathrm{Al}$.

\section{METODE PENELITIAN}

Film tipis SnSe disediakan dengan metoda evaporasi vakum model masing-masing dengan kemurnian 5N disediakan perusahaan Balzers Co. Film tipis yang dibuat dua sumber evaporasi terdiri boat molybdenum. Tekanan tabung vakum selama pemendapan kurang dari 10"4 Torr, kadar endapan 0,2 nm/dt untuk mendepositkan lapisan Sn dan Se diatas subtract kaca pada suhu kamar dengan perbandingan ketebalan Sn:Se 100/100 nm (1:3), ketebalan film ditentukan oleh hablur kuartza FTM 5 digital. Kemudian lapisan film tipis SnSe dipanaskan didalam tabung kaca dengan dialiri gas argon murni selama 3 jam pada suhu 150-40 C serta didinginkan secara perlahan-lahan.

Sebelum mengukur konstanta dielektrik, film tipis SnSe dipastikan struktur SnSe dengan menganalisa XRD (difraksi sinar-X), yaitu radiasi Cuko dengan filter nikel, http://mahesainstitute.web.id/ojs2/index.php/Jons 
kemudian persentase berat, elemen Sn dan Se. dianalisa dengan metode pendarflour sinar-X (XRF).

Untuk menghasilkan kapasitor film tipis SnSe, elektroda logam aluminium diendapkan (dilapisi) pada bagian bawah dan atas sample sehingga diperoleh sampel dalam bentuk terapit $\mathrm{Al} / \mathrm{SnSe} / \mathrm{Al}$ dengan kawasan ukur yang efektif 5,89x110 $\mathrm{m}^{-2}$.

Untuk mengukur konstanta dielektrik disediakan lima sample dengan ketebalan sample $10 \mathrm{~nm}, 200 \mathrm{~nm}, 300 \mathrm{~nm}, 400 \mathrm{~nm}, 500 \mathrm{~nm}$. Kapasitansi masing-masing diukur pada frekuensi $10 \mathrm{KHz}$ di dalam vakum pada suhu kamar. Untuk pengukuran kepasitansi sample Al-SnSe-Al dengan ketebalan SnSe $200 \mathrm{~nm}$ pada suhu pengukuran jangkauan 228-373K, sedangkan frekuensi 8-200 KHz. Peralatan analisis yang digunakan adalah perangkat Hewlett-Packard 4192 A LCZ.

\section{HASIL DAN PEMBAHASAN}

Sruktur analisis XRD pada bahan SnSe dengan perbandingan tebal (1:1) disepuh pada suhu $150^{\circ} \mathrm{C}, 200^{\circ} \mathrm{C}, 250^{\circ} \mathrm{C}$ selama 3 jam yaitu dengan nilai puncak indeks miller yang tinggi (111) dan (031) pada suhu $150^{\circ} \mathrm{C}$ selama 3 jam,' sedangkan pada suhu $200^{\circ}$ C, selama 3 jam dengan ketebalan (1:1) dengan puncak rendah yaitu (201), (Oil) dan (411), nilai sample SnSe ini sesuai dengan nilai standart pada JCPDS.

Ukuran butiran diperhitungkan dengan data analisis XRD untuk sruktur SnSe yang standart dengan menggunakan persamaan (1), schererr yaitu :

$$
t=\frac{0,9 \lambda}{B \operatorname{Cos} \theta}
$$

Dimana t ukuran butiran, 1 panjang gelombang sinar-X yang digunakan, B lebar sudut puncak struktur yang intensitas maksimum dan sudut difraksi XRD, maka diperoleh ukuran butiran hablur diantara 13,82-37,65 nm untuk sample SnSe.

Analisis pendarflour sinar-X 9XRF), dimana diperoleh persntase berat atom Sn bertambah mengikuti suhu sepuh, sedangkan persentase berat Se berkurang. Hal ini disebabkan oleh titik lebur Se lebih rendah dari pada Sn sehingga lebih banyak bahan Se yang hilang selama pemanasan (sepuh). Untuk film tipis yang disepuh pada suhu 
$200^{\circ} \mathrm{C}$ selama 3 jam (SnSe) sama dengan 71,3\% untuk bahan Sn dan 28,3\% Se, sedangkan film tipis yang disepuh pada suhu $250^{\circ} \mathrm{C}$ selama 3 jam (SnSe) diperoleh $74,5 \%$ Sn dan 25,5\% Se. Secara stoikiometri, persentase berat atom Sn dan Se dalam senyawa SnSe adalah 60\% Sn dan 40\% Se.

Secara umum kepasitas (C) dibentuk diantara dua plat sejajar yang terpisah oleh bahan dielektrik dengan ketebalan (d) dapat dituliskan dengan persamaan (2).

$$
\mathrm{C}=\frac{\varepsilon_{r} \varepsilon_{0} A}{d}
$$

Dengan $\varepsilon_{r}, \varepsilon_{0}=8.854 \times 10^{-12} \mathrm{~F} \mathrm{~m}^{-1}$ dan A adalah masing-masing konstanta bahan dielektrik, konstanta dielektrik ruang vakum dan luas daerah berkesan (yang diukur). Dari gambar 1 dapat diperhatikan grafik yang diperoleh adalah berbentuk agak melengkung. Kapasitansi film tipis SnSe berkurang apabila ketebalan film bertambah sesuai dengan persamaan (2). Untuk menentukan konstanta dielektrik film tipis SnSe, disediakan dengan 5 sampel dengan ketebalan berbeda dan luas daerah berkesan 5,89x10-6 $\mathrm{m}^{-2}$ dari kapasitansi untuk struktur terapit $\mathrm{Al} / \mathrm{SnSe} / \mathrm{Al}$. konstanta dielektrik saput dapat diperkirakan dengan memplotkan grafik kapasitansi diukur pada frekuensi tetap yaitu $100 \mathrm{kHz}$ yang ditunjukkan dalam gambar 2. nilai kemiringan (slop) dari garis lurus grafik ini adalah $6.33 \times 10^{-16} \mathrm{FM}=\varepsilon_{\mathrm{r}}, \varepsilon_{0}$ A dari sini konstanta dielektrik film, $\varepsilon_{\mathrm{r}}$ dapat ditentukan. Dari gambar 2, menunjukan grafik hubungan antara kapasitansi, C dengan. Dari grafik ini diperoleh garis linear yang tidak melalui titik asal sumbu grafik dan memotong C pada 6,93x1 $\mathrm{CT}^{9} \mathrm{~F}$. Keadaan ini berlaku karena bentuk suatu kapasitansi sejajar $\mathrm{C}_{\mathrm{p}}$ dan kapasitansi bahan ( $\mathrm{Cb}$ ) yang mengahsilkan kapasitansi hampir mengikuti persamaan (3)

$$
\mathrm{C}=\mathrm{C}_{\mathrm{b}}+\mathrm{C}_{\mathrm{p}}=\frac{\varepsilon_{r} \varepsilon_{0} A}{d}+\mathrm{C}_{\mathrm{p}}
$$

Nilai konstanta dielektrik yang ditentukan dari grafik adalah, $E r=12,13$ dan nilai kapsitansi sejajar dari persamaan (3), $\mathrm{Cp}=6,93 \mathrm{nF}$. Nilai konstanta dielektrik, Er yang diperkirakan hampir sama dengan nilai film tipis SnSe yaitu 13,38 yang telah diselidiki oleh Logothetidis dan Palatoglou, 1987) (4) yang dibuat dengan metoda Ellipsometri. 
Ketergantungan kapasitansi terhadap frekuensi untuk struktur terapit $\mathrm{Al} / \mathrm{SnSe} / \mathrm{Al}$, pada suhu yang berbeda-beda, dapat lihat pada gambar 3. Pada frekuensi kurang dari 50 $\mathrm{KHz}$, ternyata kapasitansi tergantung terhadap frekuensi dimana berkurang secara mendadak apabila frekuensi bertambah terutama pada suhu tinggi. Pada frekuensi lebih besar dari $50 \mathrm{kHz}$, diperoleh bahwa kapasitansi hampir konstan. Sementara itu, pengaruh suhu dapat juga lihat pada grafik tersebut dimana pada frekuensi rendah (kurang dari $50 \mathrm{kHz}$ ), kapasitansi sangat dipengaruhi suhu (bertambah mengikuti suhu), sedangkan pada frekuensi lebih dari $50 \mathrm{KHz}$ kapasitansi menjadi konstan terhadap suhu. Pada frekuensi lebih tinggi dapat dilihat bahwa ujung-ujung kanan kurva di dalam grafik menggambarkan suhu yang berbeda-beda seperti menuju pada satu titik.

Hal serupa dapat diamati dari grafik kapasitansi yang dapat diplotkan terhadap suhu untuk berbagai frekuensi seperti gambar 4 . berdasarkan gambar 4 dapat diuraikan bahwa pada suhu kurang $300 \mathrm{~K}$ kapasitansi hamper konstan kecuali untuk frekuensi 5 KHz. Kapasitansi yang bernilai konstan terhadap suhu sangat jelas teramati pada frekuensi $125 \mathrm{KHz}$ atau lebih. Dimana diperoleh suatu kurva yang mendaftar terhadap perubahan suhu.

Mikrostruktur dari film tipis SnSe yang sepuh pada suhu $200^{\circ} \mathrm{C}$ selama 1 jam, 3 jam, 6 jam dan 9 jam dengan alat SEM (Mikroskop scan elektron) seperti gambar (5), dapat dilihat struktur film tipis SnSe (1:1) bersifat Polihablur dengan ukuran butiran kurang lebih 1 urn. efek masa sepuh tidak banyak pengaruh sifat butiran film tipis, hal ini dapat dilihat pada ukuran butiran tidak menunjukan perubahan terhadap masa sepuh.

\section{SIMPULAN}

Kapasitansi arus bolak-balik pada kapsitor film tipis timah selenide (SnSe) sangat dipengaruhi oleh frekuensi dan suhu. Pada frekuensi rendah, pengaruh itu sangat kuat pada kapasitansi, sedangkan pada frekuensi tinggi (lebih dari $50 \mathrm{KHz}$ ) kapasitansi hamper tetap dan ukuran butiran tidak pengaruh terhadap masa sepuh. 


\section{DAFTAR PUSTAKA}

Asanabe, S,. (1959). Electrical properties of stannous selenide. J. Phys. Soc. Japan 14,281-296.

Chun, D. Walser, R.M., Bene, R.W. and Courtney, T.H. (1974).Polarity dependent memory switching in device SnSe and SnSe 2 crystals, Appl, Phys. Letters, 24, 479-481.

Gould, R.D., Gravano, S. and Ismail, B. B. (1995). "A model for frequency capacitance in cadmium telluride thin films." Thin Solid Film, 198 ; 93-102.

Hutagalung S.D, (1997). Studies on SnSe and SnSe2 thin films semiconduktor, Ph,D. Thesis, University Tehnologi Malaysia.

Maissed, L.I. ,and glang, R. (1970). Handbook of thin film technology. USA Mc Graw Hill, 
